\title{
Assessing the Policy Provisions and Institutional Behavioral Factors Influencing Rail Infrastructure Financing in Developing Countries

\author{
De-Graft Owusu-Manu', David Edwards' ${ }^{2}$, Frank Ato Ghansah ${ }^{3}$, Richard O. Asiedu ${ }^{4}$, Dan \\ Steven N. Tagoe ${ }^{5}$, and Tony Birch ${ }^{6}$
}

${ }^{1}$ Professor, Department of Construction Technology and Management, Kwame Nkrumah University of Science and Technology, Ghana

Email: d.owusumanu@gmail.com
${ }^{2}$ Professor, School of Engineering and the Built Environment, Birmingham City University, UK
Email: drdavidedwards@aol.com
${ }^{3}$ Student, Department of Construction Technology and Management, Kwame Nkrumah University of Science and Technology, Ghana
Email: phrankatos@gmail.com

${ }^{4} \mathrm{PhD}$, Faculty of Built and Natural Environment, Department of Building Technology, Koforidua Technical University, Ghana

Email: richasiedu27@yahoo.com
${ }^{5}$ Student, Department of Construction Technology and Management, Kwame Nkrumah University of Science and Technology, Ghana
Email: aposteve.dan1@gmail.com

${ }^{6} \mathrm{PhD}$, School of Engineering and the Built Environment, Birmingham City University, UK

Email: Tony.birch@bcu.ac.uk

\begin{abstract}
Purpose: Financing rail infrastructure development in developing countries has hitherto received scant academic attention, especially in empirical developments. This research study assesses the policy provisions and institutional behavioral factors influencing rail infrastructure financing in developing countries such as Ghana.

Methodology: An empirical and positivist epistemological lens was adopted using triangulation between deductive and inductive approaches to test three hypothesis. Methods adopted included questionnaire survey and interviews to gather primary data, and inferential statistics such as Bivariate Linear Regression Analysis.
\end{abstract}


Findings: Factors identified that inhibit rail infrastructure development in developing countries include: ineffective monitoring and evaluation, a largely neglected rail sector and archaic financing posture. Based upon the findings, prescriptive guidance on financing future rail infrastructure for policymakers and governments is delineated.

Originality: This novel research identifies a number of interventions, that if implemented, will engender socio-economic and regional inter-trade integration and prosperity to the sub-region of West Africa.

Keywords: developing countries, policy provision, rail infrastructure, infrastructure financing

\section{Introduction}

Infrastructure development is vital to engendering and sustaining a country's economic growth and prosperity (Mottaleb, 2018). However, 'infrastructure' is a heterogeneous term (Chan et al., 2009) that embraces both social infrastructure (e.g. hospitals) and economic infrastructure (e.g. rail and road networks) (Wagenvoort et al., 2010). Rail infrastructure is an essential ingredient of a modern economy (cf. Stewart, 2010) because it augments industrial productivity and stimulates public and private sector participants to invest in commercial activity (Wu et al., 2016). Ghana's rail infrastructure encompasses $947 \mathrm{~km}$ (593 miles) route length, with a track length of 1,300 km (807 miles) and was first developed in 1898 under the Gold Coast Civil Service, which has headquarters in Sekondi, in the Western region (Ekow, 2016). However, only 130Km is currently operational with freight and/or passenger services (Ghana Railways Development Authority, 2013). A combination of poor maintenance and natural deterioration has significantly reduced anticipated economic benefits thus, prompting the current government's attempts to reinvest into improving the efficiency of Ghana's rail infrastructure system. However, Soroush 
(2016) stressed that the lack of innovation in financing infrastructure projects is the most important challenge confronting both government and industry.

Assorted theoretical underpinnings on infrastructure financing are available to fund rail infrastructure developments over a wide range of financing vehicles (Stojić et al., 2012). To date, Ghana has opted for a mixture of public and private financing (such as equity capital) to finance infrastructure developments (Inderst, 2016). However, more recently, private corporations have predominantly financed and executed infrastructure projects often at higher cost to government (Verhoest et al., 2013). Consequently, developing countries face daunting challenges in addressing financial needs to develop affordable railway infrastructure and engendering sustainable economic growth (World Bank, 2006; Saif et al., 2016). Yet despite its importance, financing rail infrastructure development in developing countries has not been adequately investigated within prevailing literature (Badu et al., 2012; Kodongo and Ojah, 2016). This research fills that knowledge gap by assessing the policy provisions and institutional behavioral factors influencing rail infrastructure financing in the developing country of Ghana (as a case study). Concomitant objectives are to: explore policy provisions that regulate financing rail infrastructure development; examine behavioral factors of institutional oversight that affect finance decisions made; and evaluate contemporary financing vehicles.

\section{Overview of Rail Infrastructure Financing in Developing Countries}

A systematic review of the Scopus database (using the keywords 'rail infrastructure development in developing countries') reveals that only 79 publications were available. For this small secondary data set, it is apparent that interest in the area has slowly increased since 2004 but mainly in developed countries. Only four publications were produced by African developing 
countries and this could indicate that developed western nations will continue to deliver Africa's rail infrastructure needs. Such may assist with knowledge transfer but could also be more costly for developing countries. Moreover, this trend indicates a lack of research and development in this area thus, justifying the need for this present study. Many African countries that are transitioning from vastly under development to developing countries face a daunting task of raising affordable finance for building infrastructure. Foster and Briceno-Garmendia (2010) opined that, although infrastructure accounts for more than half of Africa's recent growth performance, it can achieve further growth. In sharp contrast, the African Development Bank [ADB] (2015) reports that a growth rate of $7 \%$ is required to meet the Millennium Development Goals (MDGs) designed to achieve poverty reduction. An analysis of countries' budgetary allocation to infrastructure conducted by the Infrastructure Consortium for Africa [ICA] (2013) reveals that differences among sub-Saharan African countries vary remarkably. The study shows that: "South Africa continues to dominate the continent in terms of absolute national budget allocations. At about $\$ 29.1$ billion, South African infrastructure spending in 2012 was by far the largest in sub-Saharan Africa. After South Africa, Kenya and Namibia spent the most at about $\$ 3.0$ billion each in 2012. Tanzania and Ethiopia spent about $\$ 1.7$ billion each. South Africa will likely continue to be the country with the largest absolute infrastructure allocation funded through its domestic budget." Fay et al. (2011) as cited by Gutman et. al. (2015) estimates developing countries must invest 5-6\% of their Gross Domestic Product (GDP) in infrastructure to sustain their economic growth. Ghana's budgetary allocation falls short of this estimate as it currently invests only $2 \%$ to $3 \%$ of its GDP.

\section{Policy Provisions Regulating Infrastructure Development}


Infrastructure policy provisions are a key area of focus for governments globally because of the need to match financial needs to infrastructure development targets set. Governments must therefore enact legislative instruments that tactically and strategically translate into new laws and/or legal reforms that facilitate infrastructure development (Rondinelli et al., 1989; Odongo, 2012; Slatvitskaya et al., 2017). Infrastructure policies focus government attention onto optimizing resource allocations amongst competing national projects (Luiz, 2010). Infrastructure policy options range from: planning national infrastructure provisions strategies; and defining suitable financing options that would serve as vehicles to attract sector investment (ibid). This current study argues that notwithstanding varied policy provisions, the intended purpose or goals of a regulatory policy may be partially or completely frustrated in the absence of policy coherence (Stern and Holder, 1999; Xu et al., 2019). Without coherence in policy provisions, harmony between policy implementation programs is disrupted; consequently, governing authorities lose their credibility and legitimacy when projects conflict each other with negative impacts. Thus, governments must create transparent regulations and laws out of genuine interests to provide much needed 'public good' without recourse to partisanship. Consequential externalities affect general economic prospects and development across the divisions of public governance, with public initiated infrastructure projects abandoned by successive governments (Luiz, 2010). Often this institutional misappropriation is intended to denigrate erstwhile governments which in turn, hampers growth and development.

\section{Institutional Behaviors Underpinning Financing Rail Infrastructure}

Suri (2012) suggests that organizational management behaviors is a distinct field of investigation that encapsulates human attitude, performance and behavior in firms and consequently, draws 
upon other disciplines such as political science, sociology, anthropology and psychology. Exemplars of research undertaken include: Zameer et al. (2018) who studied organizational management behavior as a result of emotional contagion experienced by selected members in a distinct organization. Keah et al. (2016) described a charting technique to help organizations determine whether different variables are combining to produce an environment that encourages positive workplace behavior. Suri (2012) asserts that the charting technique can determining whether organizational goals, performance measures and reward systems are congruently reinforcing together with workplace task and situation conditions. Similarly, organizational management behaviors invariably impact upon rail infrastructure finance. Rail infrastructure regulatory concerns and administration is predominantly the preserve of governments within developing countries (Foster and Briceno-Garmendia, 2010). Nonetheless, agencies charged with responsibility for delivering infrastructure are seldom given the managerial and financial autonomy needed to perform (Luiz, 2010). Rodima-Taylor and Grimes (2019) argues that assessing the poor performance of infrastructure in Africa (and other developing countries) requires an in-depth understanding of the institutional arrangements and incentives governing its delivery. According to Chan et al. (2009), policies could be enacted and promulgated by governments to deliver integrated transport systems. Nonetheless, the government's institutional influence is a catalyst (that when inadequately managed) could annul the very objective of any infrastructure initiative.

\section{Precis of Rail Infrastructure Network in Ghana}

Ghana's railway infrastructure network serves a population of about twenty-five million people (Railway Master Plan of Ghana, 2013). Its existing railway network is predominantly confined to 
the country's comparatively economically developed southern region. The current rail network is designated into divisional lines called the Western, Eastern and Central lines with five (5) branch lines viz: the Sekondi, Prestea, and Awaso branch lines (originating from the Western line); and the Tema branch (originating from the Eastern Line, and Kade branch) (Fay et al., 2011). The railway network resides in a deplorable state with only circa $130 \mathrm{~km}$ of line $(9 \%)$ operational. Maintenance and development of rail infrastructure currently lags behind the road network that constitutes the country's main transport system and currently covers about $67,450 \mathrm{~km}$ as at 2010 . Currently, road transportation caters for circa $95 \%$ of Ghana's overall transport network system. This imbalance in infrastructure provisions is contradictory to guidance emanating from developed countries which promote an effective rail system. Moreover, independent reports suggest that Ghana's government remain ambivalent to the inherent value of rail infrastructure (Maxwell Investment Group, 2019). Instead, government efforts remain focused upon rehabilitating and constructing new road construction (Railway Master Plan of Ghana, 2013). Despite the prevailing political climate and decisions hitherto taken, Ghana's government is planning to budget $\$ 21$ billion to repair and upgrade railway infrastructure to full functionality (Maxwell Investment Group, 2019). This in addition to a signed contract worth $\$ 3$ billion with South Africa to construct Accra Sky Train to serve as an efficient solution to the increasing traffic congestion in Accra City, Ghana. Cumulatively, it is envisaged that this investment will provide an effective railway network that can contribute to intercontinental and international trade, creating buoyant macroeconomic implications (Maxwell Investment Group, 2019).

\section{Contemporary Rail Infrastructure Financing Vehicles}


A competing variety of financing vehicles could deliver rail infrastructure delivery in a costeffective and efficient way. These include: general budget appropriations; specific-purpose and scrutinized borrowing; public-private partnerships; concessions and franchises; and project finance and private equity. (World Bank, 2006; Hart, 2016).

\section{- General Budget Appropriations}

Financing of rail infrastructure by public funds raised via general budget appropriation is historically the oldest method employed to finance rail infrastructure projects (Estache et al., 2002). Chong and Poole (2013) added that the public perceive this method to provide greater transparency and higher scrutiny when compared to alternative financing options.

\section{- Specific-Purpose and Securitized Borrowing}

Specific-purpose borrowing is another well-established tool used locally and internationally to source funding for large government infrastructure projects (Torvanger et al., 2016). It utilizes both internally borrowed funds from private corporations (e.g. the banking sector) and public external funding from bilateral agreements (e.g. long-term loans) (Allen et al., 2019). Chan et al. (2009) defines securitized borrowing as the issuance of debt instruments (such as bonds and debentures) to finance infrastructure by the public sector which is asset-backed. These instruments are mainly issued by central governments to finance government projects.

\section{- Public-Private Partnership (PPP)}

The World Bank (2012) defines PPP as a contract between government and a private entity to provide a public asset, for which a significant risk and management responsibility is borne by the private entity. PPP can inflate infrastructure development costs because of the higher cost of private financing when compared with government debt (Chong and Poole, 2013).

\section{- Concessions and Franchises}


Concessions and franchises are effective forms of increasing private sector participation in executing public projects such as infrastructure development, operations and maintenance (World Bank, 2015). Concession contracts diversify government infrastructure project risks whilst simultaneously engendering market competition. The Organization for Economic CoOperation and Development (2007) prescribes principles in granting concessions and risk apportionment criteria for private sector participation.

\section{- Project Finance and Private Equity}

Project finance and private equity are key innovative ways of financing infrastructure projects. Owusu-Manu (2013) explains that project finance as a mix of financial and business engineering that involves non-recourse financing of a project. Revenues generated by the project are the principal funds relied upon for the repayment of its loan, and the project's assets are used as collateral for its loan rather than to the general credit of the project sponsor.

\section{Research Methods}

The infrastructural sector is an observable social reality requiring a positivist approach to studying existing phenomenon by touching on the realism posture (Remenyi et al., 1998, Grix and Maguire, 2014). Nonetheless, this study sought to bridge the gap between various philosophical dispositions by inculcating the pragmatic stance in making reasonable conclusions. Consequently, the researcher employed varied philosophical stances to realize the study's objectives. A deductive approach was predominantly used to test existing theories (Hamad et al., 2016) but an inductive approach was also adopted to review qualitative contents collected from field interviews and published literature (Kim et al., 2017). A case study of the developing country of Ghana was used as an exemplar that could facilitate statistical inference to be drawn 
for other developing countries (International Statistical Institute, 2017). Strategically, this study used triangulation (Heale and Forbes, 2013; Edwards and Holt, 2010); where both qualitative and quantitative data strategies were deployed to collect data, and obtain robust analysis and findings. Triangulation confirms findings from divergent points of analysis thus, augmenting validity of the findings. A qualitative approach using structured interviews as a primary data collection instrument, was used to explore policy provision intentions or contents whilst a quantitative approach sought to collate data using a structured questionnaire. Purposive sampling was used to sample the varied survey respondents who consisted of personnel working in Ghana Railway Development Authority who occupy various positions ranging Senior Technical Officers, Procurement Officers, Heads of IT, Senior Estate Officers and Administrative Officers. Descriptive and inferential analysis was used to analyze the respondent's background information. The study also adopted bivariate linear regression analysis and analysis of variance (ANOVA) to determine the relationship between sufficient budget allocation and rail infrastructure development. Descriptive quantitative analysis was also used to ascertain how respondents prioritize the significant variables found. Pearson's Correlations were adopted to test if: the financial vehicle (i.e. independent variable) has a significant impact on rail infrastructure development (i.e. dependent variable); and if institutional oversight behavioral factors (i.e. independent variables) has a significant impact on rail development (i.e. dependent variable). Lastly, linear regression was run to test if sufficient budget allocation (i.e. independent variable) can impact rail infrastructure development (i.e. dependent variable).

\section{Hypothesis Testing}


The study considered the rail infrastructure financing vehicles, adequate budgetary allocation and institutional oversight behavioral factors having significant impact on rail infrastructure development in developing countries. This is confirmed by running a test on the following hypothetical statements:

\section{- Financing Vehicles}

Financing vehicles represent a contemporary form of funding rail infrastructure projects (World Bank, 2011). Hence: Ho1: Financing vehicles are catalysts that do not significantly impact upon rail infrastructure development in Ghana. Ha1: Financing vehicles significantly impact rail infrastructure development in Ghana.

\section{- Institutional Oversight Behavioral Factors}

Gowda and Mamatha (1997) argue that assessing poor performance of infrastructure development in developing countries, requires an understanding of the institutional behavior arrangements and the incentives governing its delivery. Foster and Briceno-Garmendia (2010) concurred and stated that rail infrastructure regulatory administration is predominantly the preserve of governments within developing countries. This is due to the behavioral factors involved. Hence, it is then hypothesized that: Ho2: Institutional oversight behavioral factors have a significant impact on rail infrastructure development in Ghana. Ha2: Behavioral factors of institutional oversight do not impact rail infrastructure development in Ghana.

\section{- Budgetary Allocation}

Budgetary allocations for infrastructure growth from the public purse continue to widen, particularly in countries with a fiscal shortfall (Zhou et al., 2016). It is therefore imperative to test if the budget allocation has an impact on rail infrastructure development. Hence, it is hypothesized that: Ho3: Budgetary allocations do not have a significant effect on rail 
infrastructure development in Ghana. Ha3: Budgetary allocations have a significant effect on rail infrastructure development in Ghana.

\section{Socio-Demographics of Respondents}

110 questionnaires were self-administered through email addresses and also hardcopy sent to the target population. 72 responded questionnaires were retrieved, culminating in a $65.45 \%$ response rate. The study achieved a higher response rate because the research area was highly relevant and seemed to be of concern to the respondents.

\section{<Insert Table 1 about here>}

Table 1 revealed that, the majority of the respondents were Administrative Officers (34.72\%) while the remainder were senior management officers occupying the positions of: Senior Estate Officers (12.50\%), Senior Technical Officers (16.67\%), Heads of IT (16.67\%) and Procurement Officers (19.44\%). The working experience of respondents was: $4.17 \%$ over 20 years; $6.94 \%$ between $11-15$ years; $13.89 \%$ between $0-5$ years; $16.67 \%$ between $16-20$ years and $58.33 \%$ between $6-10$ years. Thus, the views and opinions of this study were predominantly (circa $86 \%$ ) given by respondents occupying key sectorial positions who have worked for more than 6 years within the sector are knowledgeable enough to answer the proposed questions.

\section{Exploring Policy Provisions That Regulates Financing Rail Infrastructure Development}

Using a 4-point Likert item measurement ranging from 'disagree, partially agree, agree and strongly agree', the respondents' views on policy provisions were explored (refer to Table 2).

\section{<Insert Table 2 about here>}

$63.88 \%$ of the respondents 'strongly agreed' that there are clearly indicated specific policy provisions on how to operate and maintain rail infrastructure and systems in Ghana. 81.94\% 
strongly agreed that rail infrastructure development is largely dependent on government policy provisions while $59.73 \%$ also agree that policy provisions significantly impact rail infrastructure development by increasing funding to the sector. Another $55.56 \%$ agree that policy provisions significantly impact rail infrastructure development by providing the right regulatory framework. However, $45.83 \%$ agreed and $54.17 \%$ strongly agreed that policy provisions significantly impact rail infrastructure development by earmarking a specific revenue stream for investment. Therefore, participants provided clear indications that rail infrastructure development is largely dependent on, and regulated by the government's policy provisions (81.94\%). It is however not clear if strong policy provisions with distinct directions for innovative rail infrastructure financing reforms in Ghana exist (African Development Bank, 2015). This then despites Bullock's (2013) view that comprehensive standardized rail infrastructure policies are the way forward for Sub-Saharan African rail infrastructure development. To shed further light upon the findings, an in-depth interview was conducted with one of the respondents who worked for the Ghana Railway Development Authority. The respondent stated that:

"Ghana's rail development has suffered greatly in the last two decades. For it to see great improvements, there is the need to implement institutional, regulatory and administrative policies and reforms which should be fully carried out to effect operational efficiency."

\section{Hypothesis One: "Financing Vehicles are Catalysts that Significantly Impact Rail Infrastructure Development in Ghana"}

Person's Correlations test was run in the Statistical Package for the Social Scientist (SPSS), version 25 to examine the relationship between efficient financing of the rail sector and type of financing vehicles impact rail infrastructural development'. The correlation matrix illustrates that there is a strong positive linear relationship $(\mathrm{r}=.690)$ between these variables which is 
statistically significant $(\mathrm{p}<0.05)[\mathrm{n}=72, \mathrm{r}=.690, \mathrm{p}=.019]$ (refer to Table 3$)$. It is reasonable to assume therefore that, as Ghana opts for an effective financing option in the rail sector, it positively impacts and boosts the infrastructural development of Ghana Railway Authority. Thus, we reject the null hypothesis but accept the alternate hypothesis (Ha1) that 'financing vehicles are catalysts that significantly impact rail infrastructure development'. This finding concurs with the earlier work of Stojić et al. (2012).

\section{<Insert Table 3 about here>}

\section{Behavioral Factors of Institutional Oversight That Affect Financing Rail Infrastructure Development}

Again, using a 4-point Likert item measurement ranging from 'disagree, partially agree, agree and strongly agree', the respondents' views on policy provisions were explored (refer to Table 4). 72 respondents gave their views on the behavioral factors of institutional oversight that affect financing rail infrastructure development in Ghana. $63.89 \%$ of the respondents partially agree that personnel charged with the monitoring and evaluation of rail infrastructure and systems discharge their responsibilities adequately while another $62.50 \%$ disagreed with the notion that personnel charged with the maintenance of rail infrastructure are adequately equipped to do their work. However, $63.88 \%$ of the respondents strongly agreed that there are specific policy provisions on how to operate and maintain the rail infrastructure and systems.

\section{<Insert Table 4 about here>}

A further $54.17 \%$ strongly agreed that the railway act or any other regulatory policy provision compels the continuation of uncompleted projects initiated by former governments. In addition, 72.22\% strongly agreed that rail infrastructure projects have not had a balanced priority share among other alternative transport infrastructure developments. Indeed, 45.83\% strongly agree 
that partisan politics has influenced the legislative in enacting policies covering rail sector developments. It is therefore suspected that certain institutional behavioral factors influence the sector which may negatively impact upon financing rail infrastructure development. This argument is further strengthened by the 2017 / 2018 budget which records an overall budget cut with a low Government Sectoral Expenditure Allocation for Infrastructure development in Ghana (National Budget, 2017).

\section{Hypothesis Two: “Behavioral Factors of Institutional Oversight Impacts Rail Infrastructure Development"}

A Pearson correlation test was again adopted, and the result revealed the negative and weak relationship between adequate monitoring, evaluation and discharge of duties and partisan politics influence the legislative in enacting rail policies for development (i.e. revealing a Pearson Coefficient R-value of -.063 which is statistically insignificant $(\mathrm{p}>0.05)[\mathrm{n}=72, \mathrm{r}=$ $.063, \mathrm{p}=.853]$. Thus, partisan politics exhibits a negative relationship and influence on the adequate monitoring, evaluation and discharge of duties in the rail sector (refer to Table 5). Consequently, the alternate hypothesis is accepted, i.e. behavioral factors of institutional oversight impact rail infrastructure development.

\section{<Insert Table 5 about here>}

\section{Other Negative Behavioral Impact Affecting the Financing of Rail Infrastructure Development}

The research further revealed that the negative behavioral impact has affected the financing of rail infrastructure (refer to Table 6). $27.78 \%$ of respondents agreed and $72.22 \%$ strongly agreed that rail infrastructure projects have not had a fair priority share among other transport infrastructure developments. $62.50 \%$ of respondents also strongly agreed that the Ghanaian 
economy has consistently underinvested in rail infrastructure development. This is further reflected in the current status of the Ghana railway sector with the majority of respondents $(45.83 \%)$ believing that the sector has collapsed while $36.4 \%$ of them confirmed the sector in the process of collapsing. Reasons for the observed poor maintenance of rail infrastructure in Ghana include the lack of funds, regulation, monitoring and technical know-how (54.16\%).

\section{<Insert Table 6 about here>}

The findings contradict reports from Luiz (2014) who cited that productive good infrastructure (airports, ports, railways and roads) plays an important role in promoting economic growth and encouraging private investment. These economic infrastructures, when effectively and productively implemented, significantly impact upon the economy, serving as a catalyst for increasing economic activities, private investments and GDP growth. This however, is not evident in Ghana's railway sector. Secondary data/records reveal that before Ghana's independence, the country saw a growth rate of $60 \%$ in its rail infrastructure. However, after independence, only $0.1 \%$ growth rate was recorded (Luiz, 2014). Currently, only $14 \%$ of the entire rail network is operational due to poor maintenance (Oxford Business Group, 2018). The Oxford Business Group report (ibid) specifically revealed the following new policies of the rail sector in Ghana:

"The renewed focus on railways as reflected in the 2017 budget allocated GHS 518m $(\$ 124 m)$ to the Ministry of Railways Development and called for greater PPP activity.”.

"More than \$7bn would be committed to the rail sector between 2017 and 2021 to support 1394 km of routes.” (Minister of Railways Development, 2017). 
"Upgrading the railway sector will attract more trading partners to the country because costs to transport imports or cargo by road are over 50\% greater than those by rail. ,

This then portrays that the railway infrastructure in Ghana is under reformation as it is being considered in the budget allocation; a decision that has an incidental benefit of inviting investors into Ghana.

\section{Evaluating the Financing Vehicles in Financing Railway Development in Ghana}

In ascertaining the financial options that Ghana has pursued hitherto to finance its railway development, the majority of respondents $(45.45 \%)$ cited budgetary allocations from the Government as a main source of investment while $36.36 \%$ indicated loan facilities obtained from other countries. Only 9.09\% stated investment sourced from concession and project finance respectively. Modern Ghana (2017) confirmed that budgetary allocation was the Government's main rail infrastructure finance source. However, the country has recorded a decline in the budgetary allocation of railway development (cf. Bruce, 2017) viz:

"The Budget allocation to the Ministry of Railways Development was reduced from GHф518.42 million in the 2017 budget to GHф 327 million in 2018, representing a reduction rate of $36.87 \%$. This would however negatively affect the development of the sector as indicated by the World Bank that: 'to address Ghana's huge infrastructure deficit, a sustained spending of at least $\$ 1.5 b n$ per annum over the next decade is needed to plug the infrastructure gap that exists."

\section{Hypothesis Three: Budgetary Allocations Significantly Affect Rail Infrastructure}

\section{Development}


The study again employed Bivariate Linear Regression Analysis by testing hypotheses, particularly of association and causality. In this way it can be seen how much easier it becomes to know (and predict) a value of the dependent variable having known independent variable. The Regression Model:

$Y=f(x)$; $\quad$ Where $Y=$ rail infrastructure development (dependent variable);

$x=$ sufficient budget allocation (independent variable); and

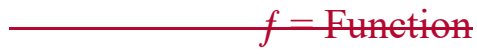

Bivariate linear regression analysis revealed an $\mathrm{R}$-value of .478 , which indicates the existence of a moderately strong and positive relationship between sufficient budget allocation and rail infrastructure development. In addition, a R-Square value of 0.332 was obtained, indicating that the perception that the respondents have with regard to "sufficient budget allocation" accounts for $33.2 \%$ of their perception towards good rail infrastructure development" (refer to Table 7A). This is a moderately good fit for the regression model; thus, rail infrastructure development is impacted upon (and influenced by) sufficient budget allocation.

\section{<Insert Table 7A about here>}

\section{Analysis of Variance (ANOVA):}

The ANOVA table displays a significant value of $.003(\mathrm{p}<.005)$ indicating that sufficient budget allocation is statistically significant enough to predict rail infrastructure development (refer to Table 7B). From the coefficients table (refer to Table 7C), sufficient budget allocation has a significant effect on rail infrastructure development $(\beta=.327, \mathrm{p}=.003)$. Put simply, a percentage increase in sufficient budget allocation would significantly affect the rail infrastructure development by $32.7 \%$. From the hypothesis, sufficient budget allocation 
significantly predicts and affects rail infrastructure development and the null hypothesis is accepted.

\section{<Insert Table 7B about here> \\ <Insert Table 7C about here>}

\section{Need for Financing Reforms for Rail Infrastructure Development}

Table 8 seeks to support the findings of linear regression analysis conducted. The majority of respondents (54.16\%) strongly agreed that the type of financing option deployed for rail infrastructure development influences the level of investment in the sector. Moreover, $72.22 \%$ totally disagreed that there is a specifically earmarked government revenue stream for financing railway infrastructure development. Hence, $81.94 \%$ strongly agreed that Ghana requires financing reforms to fund rail infrastructure project. The type of financing option deployed for rail infrastructure development influences the level of investment in the sector as strongly agreed by $54.16 \%$ of the respondents.

\section{<Insert Table 8 about here>}

\section{Discussion: Outcomes, Theoretical, Practical and Managerial Implications}

In exploring policy provisions that regulate financing rail infrastructure development, the study's findings revealed that there are specific policy provisions on how to operate and maintain rail infrastructure and systems which are largely dependent on government policy provisions. The importance of increasing funding to the sector was indicated with the need to provide the right regulatory framework and policy provisions for financing rail infrastructure in Ghana. Although there are clear indications that rail infrastructure development is largely dependent on, and regulated by the government's policy provisions, it still remains unclear as to whether existing 
policy provisions are strong enough to facilitate innovative rail infrastructure financing reforms in Ghana. Theoretically, the findings further revealed a strong positive linear and statistically significant relationship between efficient financing and the type of financing options to use for rail infrastructural development which are catalysts for economic growth.

In addition, personnel charged with the maintenance of rail infrastructure were not adequately equipped to do their work effectively, and rail infrastructure projects did not have a fair priority share among other transport infrastructure developments. Partisan politics was also observed to have influenced legislative policies covering rail sector developments (or rather the lack of them). It was evident that institutional behavioral factors negatively influenced the sector with resultant effects reflected on the overall budget cut with a low Government expenditure allocation for infrastructure development. A negative relationship was revealed between partisan politics and adequate monitoring and evaluation of duties in the rail sector. Because the Ghanaian economy has hitherto underinvested in rail infrastructure development (due to a notable lack of funds, regulation, monitoring and lack of technical know-how), many respondents cited that the rail sector is in the process of either collapsing or has collapsed. Indeed, at present only $14 \%$ of the entire rail network is recorded as being operational.

In evaluating financing vehicles that Ghana pursues in financing railway development, the study revealed that budgetary allocations from the Government and loans obtained from other countries were the main financing options that Ghana engages in. However, the country recorded a decline in the budgetary allocation for the railway sector, although regression analysis conducted revealed a moderately strong and positive relationship between the provision of sufficient budget allocation and rail infrastructure development. Hence, sufficient budget allocation significantly predicted rail infrastructure development for sector growth and economic 
development. As revealed, because financial vehicles are catalysts for rail infrastructure development, there is the need for Ghana's government to opt for an effective and sustainable financing option; and also earmark a specific revenue stream for financing rail infrastructure development. Practically, the study recommends that all stakeholders in the sector should implement organizational, administrative and regulatory reforms to effect rail operational efficiency. It is, therefore, imperative to adhere to international standards to comply with rail infrastructures in the developed countries. The study also proposes that periodic auditing needs to be enforced to hold all stakeholders accountable to efficiently discharge their responsibilities. The study will help in providing a clear decision path for policymakers, governments and all stakeholders associated with rail infrastructure development. It will also serve to engender much needed (and wider) debate in this important area of economic development for developing countries. The study's findings provide new insights into financing reforms that support rail infrastructure developments, especially the strategy of deploying innovative ways of financing rail infrastructure.

\section{Conclusion}

This current study assessed the policy provisions and institutional behavioral factors influencing rail infrastructure financing in developing countries. Many countries have developed due to huge investments made in the railway sector to boost economic activities. The population of Ghana has outgrown the road transport usage ratio, leading to a series of unsustainable congestions, human and vehicular traffics. Inter-trade activities amongst cities have been woefully limited with crippling effects upon the economy. Ghana, thus needs to invest heavily in rail 
infrastructure development in this 21 st century to promote economic growth and create a vibrant business environment for major investments and partnerships.

The socio-demographic data for this study included personnel of Ghana Railway Development Authority who occupy various positions ranging Senior Technical Officers, Procurement Officers, Heads of IT, Senior Estate Officers and Administrative Officers. The finding of the study uncovered how the risk of policy provisions, financing options, institutional oversight and budgetary allocation could be managed to bridge the financing deficit in rail infrastructure development in Ghana. The contribution of this study to knowledge is the discovery that, efficient financing and the type of financing options to use for rail infrastructural development are catalysts for economic growth. The significance of the study is to provide a clear decision path for policymakers, government and all stakeholders associated with rail infrastructure development. Given ten (10) regional capitals of the Ghanaian economy as representative country with rail infrastructure development sparsely spread across the country, the study is geographically limited to the three (3) main railway lines namely: Western, Central and Eastern lines covering $340 \mathrm{Km}, 240 \mathrm{Km}$ and $330 \mathrm{Km}$ respectively.

In addition, the fact that this is a perception survey and therefore longitudinal action research may be required to test perceptions in practice. The sample size was relatively small and that a larger sample size may be required to include politicians, etc. Inference to other neighboring West African or developing countries can possibly be determined via comparative analysis being conducted in the future. Also, multiple regression may be adopted to produce stronger predictions. Also, another limitation of the study is the adoption of the Likert scale: $3: 1$ with positive answers, and does not contain a neutral response. There could be limitation but does not affect the generalization of the result of the study. Taking notice and considerations of the 
findings, limitations and conclusions, this study provides trends in rail infrastructure developments on the global scale out of which developing countries can learn from, as well as serving as a basis upon which further research work could be carried out to improve railway infrastructure development frameworks. With regards to the Likert scale 3:1 adopted, there could be a different approach which can be considered, since the traditional Likert scale development discourages the use of a neutral response. Again, the study further suggests that there is a whole host of future work ranging from identifying the right and best policies to implement, through to working with neighboring countries to ensure that Ghana's rail can travel cross borders to bolster trade and commerce further.

\section{Data Availability Statement}

Some or all data, models, or code generated or used during the study are available from the corresponding author by request. The list includes data collected and coded in SPSS format.

\section{REFERENCES}

African Development Bank. 2015, Rail Infrastructure in Africa: Financing Policy Option, Washington, DC., The World Bank Press.

Allen, F., Qian, M. and Xie, J., 2019. Understanding informal financing. Journal of Financial Intermediation, 39, pp.19-33.

Badu, E., Edwards, D.J., Owusu-Manu, D. and Brown, D.M. 2012, "Barriers to the implementation of innovative financing (IF) of infrastructure", Journal of Financial Management of Property and Construction, 17(3), pp. 253-273. https://doi.org/10.1108/13664381211274362.

Bruce, V., 2017. (ed). Recognizing faces. (1t ed), London, Routledge, pp. 166.

Bullock, R. 2013. "Taking Stock of Railway Companies in Sub-Saharan Africa." Background Paper 17, Africa Infrastructure Sector Diagnostic, World Bank, Washington, DC.

Chan, C., Forwood, D., Roper, H., and Sayers, C. 2009, Public Infrastructure Financing - An International Perspective, Australia, Productivity Commission Staff Working Paper.

Chatterjee, S. 2005, Poverty reduction strategies - Lessons from the Asian and Pacific Region on Inclusive development, Asian Development Review, 4(22), pp. 12-44.

Chong, S. and Poole, E., 2013. Financing infrastructure: a spectrum of country approaches. RBA Bulletin, September, pp.65-76. 
Edwards, D. J. and Holt, G. D. (2010) The case for '3D triangulation' when applied to construction management research. Construction Innovation, 10(1), pp. 25-41.

Ekow, E.M. 2016, Funding remains a key challenge for railway transport (online), B\&FT, Jan 2016 [Accessed on April 2017]. Available at: http://thebftonline.com/business/economy/16815/funding-remains-key-challenge-for-railwaytransport.html.

Estache, A., Foster, V. and Wodon, Q. 2002, Accounting for Poverty in Infrastructure Reform: Learning from Latin America's Experience, WBI Development Studies, Washington, DC: The World Bank.

Fay, M., Toman, M., Benitez, D. and Csordas, S., 2011. Infrastructure and sustainable development. Postcrisis Growth and Development: A Development Agenda for the Nation, 20(22), pp.329-382.

Foster, V. and Briceño-Garmendia, C. 2010, Africa's Infrastructure: A Time for Transformation, 2nd ed., Washington, DC: World Bank Press.

Foster, V., and Pushak, N. 2015, Ghana's infrastructure: A continental perspective (English), Policy Research working paper; Iss. WPS 5600. Washington, DC: World Bank.

Ghana Railways Development Authority. 2013, Railway Master Plan of Ghana-Annex 2 Environmental \& Social Management Framework, pp. 5-7.

Gowda, M.V.S. and Mamatha, B.G. 1997, "Infrastructure - the concept, role, constraints, and prospects", in Gowda, M.V.S. and Subrahmanya, S. (Eds), Infrastructure Development for Economic Growth, Deep \& Deep, New Delhi.

Grix, J. and Maguire, J., 2014. Political science and sport. Social sciences in sport, pp.191-218.

Gutman, J., Sy, A., and Chattopadhyay, S. (eds.). 2015, Financing African Infrastructure, Can the World Deliver? Global Economy and Development Publication, Brookings.

Hamad, E.O., Savundranayagam, M.Y., Holmes, J.D., Kinsella, E.A. and Johnson, A.M., 2016. Toward a mixed-methods research approach to content analysis in the digital age: the combined contentanalysis model and its applications to health care Twitter feeds. Journal of medical Internet research, 18(3), pp. 60.

Hart, J., 2016. Ghana on the go: African mobility in the age of motor transportation. Indiana University Press.

Heale, R. and Forbes, D. 2013, Understanding triangulation in research, Evidence-Based Nursing, 16(4), pp. 1.

Inderst, G., 2016. Infrastructure investment, private finance, and institutional investors: Asia from a global perspective, SSRN, pp. 39.

Infrastructure Consortium for Africa [ICA] (2013), Infrastructure Financing Trends in Africa, https://www.icafrica.org/fileadmin/documents/Annual Reports/ICA-Infra-Fin-Trends-Africa2013-Final-WEB.pdf, Accessed: 09/06/2020.

International Statistical Institute (2017), Developing Countries; World Bank Country Classifications (online) GNI per capita as calculated by the World Bank Atlas method, 2015, Available at: https://www.isi-web.org/index.php/resources/developing-countries.

Keah, C.G., Lau, K.N., Lim, M.S., Ng, C.H. and Teh, L.J., 2016. The Effectiveness of Conducive Work Environment Towards Work Engagement of Manufacturing Industry in Perak (Doctoral dissertation, UTAR).

Kim, H., Sefcik, J.S. and Bradway, C., 2017. Characteristics of qualitative descriptive studies: a systematic review. Research in nursing \& health, 40(1), pp.23-42.

Kodongo, O. and Ojah, K., 2016. Does infrastructure really explain economic growth in Sub-Saharan Africa? Review of Development Finance, 6(2), pp.105-125.

Luiz, J. (2010, Infrastructure investment and its performance in Africa over the course of the twentieth century, International Journal of Social Economics, 37(7), pp. 4.

Luiz, J. 2014. Infrastructure investment and its performance in Africa over the course of the twentieth century. International Journal of Social Economics, 37(7): 512-536. 
Maxwell Investment Group. 2019. Why the \$21bn railways renovation should concern you? https://thebftonline.com/2019/features/why-the-21bn-railways-renovation-should-concern-you/, Accessed: 05/07/19.

Ministry of Railways Development. 2017, Priority Projects, http://www.mrd.gov.gh/3/2/priority-projects, (Accessed: in April 2017).

Modern Ghana. 2017, IMANI's preliminary assessment of key sectors in Ghana's 2018 budget. IMANI Ghana. Available at: https://www.modernghana.com/news.

Mottaleb, K.A., 2018. Impacts of Improved Infrastructure on Labor Allocation and Livelihoods: The Case of the Jamuna Multipurpose Bridge, Bangladesh. The European Journal of Development Research, pp.1-29.

National Budget. 2017. Budget Highlights, PricewaterhouseCoopers (Ghana), Available at http://www.pwc.com/gh/en/publications.html.

Odongo, A.O., 2012. ICT policy in Africa: a comparative study of Ghana and Kenya drawing on lessons from developed countries. In Proceedings of the 6th International Conference on Theory and Practice of Electronic Governance (pp. 192-201). ACM.

Organization for Economic Co-Operation and Development. 2007, Co-Operation and Development, OECD Annual Report 2007.

Owusu-Manu, D. 2013, Introduction to Industrial Finance, 1st ed., Ghana, Kwame Nkrumah University of Science and Technology, IDL Publication.

Oxford Business Group. 2018. Ghanaian government targets improving the country's transport network amid rising demand. Available at: https://www.oxfordbusinessgroup.com/overview/.

Railway Master Plan of Ghana, 2013. Provision of Engineering Consulting Services for The Preparation of The Railway Master Plan of Ghana, Ghana Railway Development Authority of the Ministry of Transport, Final Report, December 2013, pp.12-40.

Remenyi, D., Williams, B., Money, A. and Swartz, E. 1998, Doing Research in Business and Management: An Introduction to Process and Method, London: Sage.

Rodima-Taylor, D., Grimes, W.W. 2019, International remittance rails as infrastructures: embeddedness, innovation and financial access in developing economies, Review of International Political Economy, $\quad$ https://www.scopus.com/inward/record.uri?eid=2-s2.085067698589\&doi $=10.1080 \% 2 f 09692290.2019 .1607766 \&$ partnerID $=40 \&$ md5=eddd843ef916ee f1c4b2435ae7ddaeab.

Rondinelli, D.A., McCullough, J.S. and Johnson, R.W., 1989. Analyzing decentralization policies in developing countries: a political-economy framework. Development and change, 20(1), pp.57-87.

Saif, M.A., Ghulman, B.A., Ahmed, I. and Khalil, M.H., 2016. Challenges to the Development of Railway Infrastructure in Remote and Formidable Terrain: A Case Study from Saudi Arabia, Proceedings of the Third International Conference on Railway Technology: Research, Development and Maintenance, J. Pombo, (Editor), Civil-Comp Press, Stirlingshire, Scotland.

Slatvitskaya, I.I., Mironova, D.D., Romanova, S.V. and Popova, T.D., 2017. The State's Policy on Import Substitution in The Russian Federation: Issues and prospects. Academy of Strategic Management Journal.

Soroush, M., Duffield, C., Wilson, D. 2016, Innovation in infrastructure projects: an Australian perspective, International Journal of Innovation Science, 8(2), pp. 113 - 132.

Stern, J. and Holder, S., 1999. Regulatory governance: criteria for assessing the performance of regulatory systems: An application to infrastructure industries in the developing countries of Asia. Utilities Policy, 8(1), pp.33-50.

Stewart, J. 2010, The UK National Infrastructure Plan 2010 in Strauss, H. (ed.) Public and private financing of infrastructure. Policy challenges in mobilizing finance, 15(2), pp.30.

Stojić, G., Vesković, s., Tanackov, I., Milinković, S., 2012, Model for Railway Infrastructure Management Organization, 24(2,) pp. 99-107. 
Suri S. 2012. The Impact of Organizational Behavior on Employees Behavior in Pharmaceutical Companies in Selected Locations of Maharashtra Viz; Mumbai, Pune, Nasik, PhD Dissertation, Padmashree Dr D.Y. Patil University, Navi Mumbai.

Torvanger, A., Narbel, P., Pillay, K. and Clapp, C., 2016. Instruments to incentivize private climate finance for developing countries. CICERO Report.

Verhoest, K., Carbonara, N., Lember, V., Petersen, O. H., Scherrer, W., Hurk, M. V. D. 2013, PublicPrivate Partnerships in Transport: Trends \& Theory P3T3, 1st ed., Italy, Arti Grafiche Favia Srl, Bari publishers.

Wagenvoort, R., de Nicola, C. and Kappeler, A. 2010, Infrastructure finance in Europe: Composition, evolution and crisis impact, EIB Papers, 15(1), pp. 8-9.

World Bank. 2006, World Development Report: Equity and Development, Washington, DC, The World Bank and Oxford University Press, Washington, DC, pp. 322-3204.

World Bank. 2012, Public-Private Partnerships Reference Guide, Version 1, World Bank Group, Washington DC.

World Bank. 2015, Developing countries' GNI per capita, Atlas method (current US\$ -Online), Ghana, [Accessed on April 2017]. Available at: http://data.worldbank.org/indicator/NY.GNP.PCAP.CD.

$\mathrm{Wu}$, Q., Perl, A. and Sun, J., 2016. Bigger and different: beginning to understand the role of high-speed rail in developing China's future supercities. Transportation Research Record, 2546(1), pp.78-87.

$\mathrm{Xu}, \mathrm{W}$., Huang, Y., 2019, The correlation between HSR construction and economic development Empirical study of Chinese cities, Transportation Research Part A: Policy and Practice, 126, pp.24-36.

Zameer, H., Wang, Y., Yasmeen, H., Mofrad, A.A. and Waheed, A., 2018. Corporate image and customer satisfaction by virtue of employee engagement. Human Systems Management, 37(2), pp.233-248.

Zhou, G., Mukonza, R.M. and Zvoushe, H., 2016. 10 Public Budgeting in Zimbabwe: Trends, Processes, and Practices. Public Budgeting in African Nations: Fiscal Analysis in Development Management, p.234. 
Table 1: Socio-Demographics of Respondents

\begin{tabular}{|c|c|c|}
\hline Variables & Frequency & Percentage (\%) \\
\hline \multicolumn{3}{|l|}{ Capacity of Staff: } \\
\hline Senior Technical Officer & 12 & 16.67 \\
\hline Procurement Officer & 14 & 19.44 \\
\hline Head of IT & $\underline{12}$ & 16.67 \\
\hline Senior Estate Officer & $\underline{9}$ & $\overline{12.50}$ \\
\hline Administrative Officer & 25 & $\overline{34.72}$ \\
\hline \multicolumn{3}{|l|}{ Working duration at GRDA: } \\
\hline $0-5$ years & 10 & 13.89 \\
\hline $6-10$ years & $\frac{10}{42}$ & 58.33 \\
\hline $11-15$ years & $\underline{5}$ & $\underline{6.94}$ \\
\hline $16-20$ years & $\underline{12}$ & 16.67 \\
\hline Over 20 years & $\underline{3}$ & 4.17 \\
\hline$N=72$ & & \\
\hline
\end{tabular}


Table 2: Policy Provisions Regulating Financing Rail Infrastructure Development in Ghana

\begin{tabular}{|c|c|c|c|c|c|}
\hline Variables & Agree & $\frac{\text { Partially }}{\underline{\text { Agree }}}$ & $\frac{\text { Strongly }}{\underline{\text { Agree }}}$ & $\underline{\text { Disagree }}$ & $\underline{\text { Total }}$ \\
\hline $\begin{array}{l}\text { There are specific policy provisions on } \\
\text { how to operate and maintain rail } \\
\text { infrastructure and systems }\end{array}$ & $13(18.06 \%)$ & $13(18.06 \%)$ & $7(63.88 \%)$ & $\bar{z}$ & $100 \%$ \\
\hline $\begin{array}{l}\text { Rail infrastructure development is largely } \\
\text { dependent on government policy } \\
\text { provisions }\end{array}$ & $13(18.06 \%)$ & $=$ & $59(81.94 \%)$ & $=$ & $100 \%$ \\
\hline $\begin{array}{l}\text { Policy provisions significantly impact rail } \\
\text { infrastructure development by increasing } \\
\text { funding to the sector }\end{array}$ & $43(59.73 \%)$ & $7(9.72 \%)$ & $15(20.83 \%)$ & $7(9.72 \%)$ & $100 \%$ \\
\hline $\begin{array}{l}\text { Policy provisions significantly impact rail } \\
\text { infrastructure development by providing } \\
\text { the right regulatory framework }\end{array}$ & $\underline{40(55.56 \%)}$ & $7(9.72 \%)$ & $\bar{z}$ & $25(34.72 \%)$ & $100 \%$ \\
\hline $\begin{array}{l}\text { Policy provisions significantly impact rail } \\
\text { infrastructure development by earmarking } \\
\text { a specific revenue stream for financing } \\
\text { rail infrastructure }\end{array}$ & $33(45.83 \%)$ & $\bar{z}$ & $39(54.17 \%)$ & $\bar{z}$ & $100 \%$ \\
\hline
\end{tabular}


Table 3: Pearson's Correlations Matrix between Efficient Financing and Rail Infrastructural

$\underline{\text { Development }}$

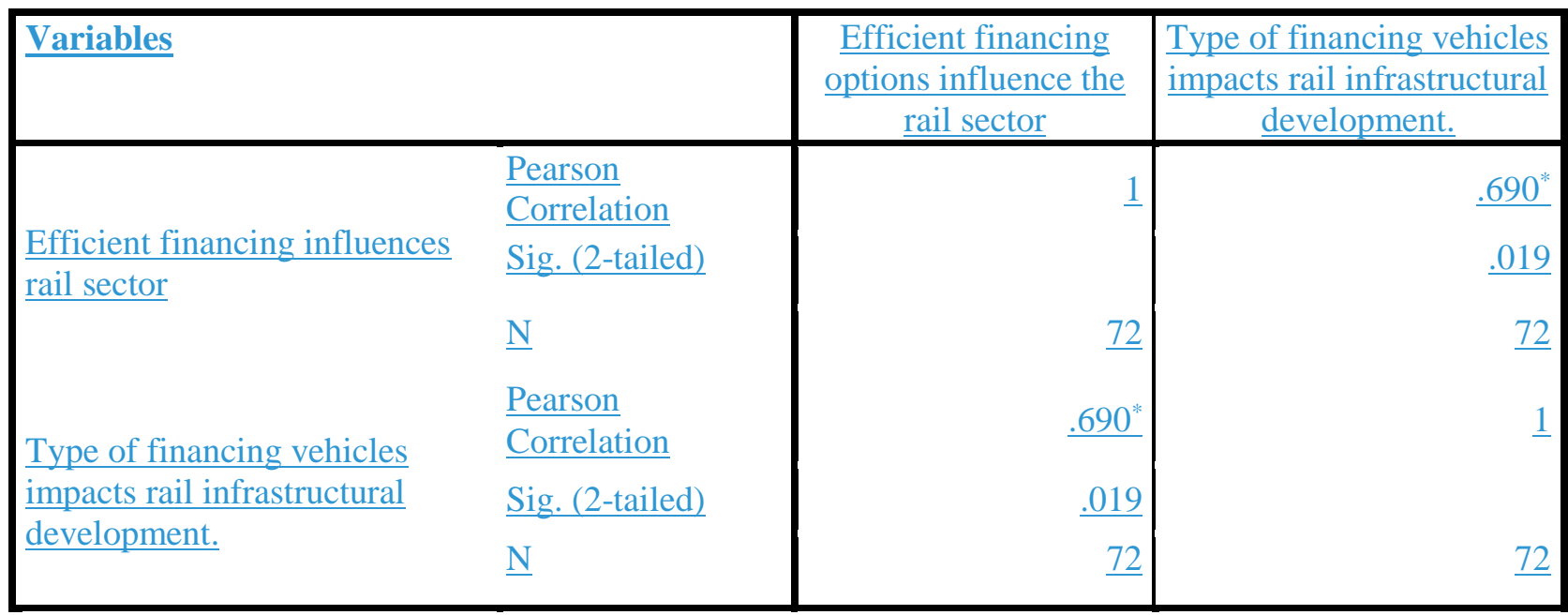

*. Correlation is significant at the 0.05 level (2-tailed). 
Table 4: Behavioral Factors that Affect Financing Rail Infrastructure Development in Ghana

\begin{tabular}{|c|c|c|c|c|c|}
\hline Variables & Agree & $\begin{array}{r}\text { Partially } \\
\text { Agree }\end{array}$ & $\begin{array}{r}\text { Strongly } \\
\text { Agree }\end{array}$ & Disagree & $\begin{array}{l}\text { Per } \\
\text { cent }\end{array}$ \\
\hline $\begin{array}{l}\text { Personnel charged with the } \\
\text { monitoring and evaluation of rail } \\
\text { infrastructure and systems } \\
\text { discharge their responsibilities } \\
\text { adequately }\end{array}$ & $\underline{20(27.78 \%)}$ & $46(63.89 \%)$ & $6(8.33 \%)$ & $\bar{z}$ & $100 \%$ \\
\hline $\begin{array}{l}\text { Personnel charged with the } \\
\text { maintenance of rail infrastructure } \\
\text { are adequately equipped to do } \\
\text { their work }\end{array}$ & $\bar{z}$ & $27(37.50 \%)$ & 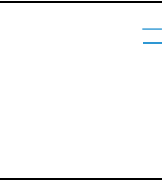 & $45(62.5 \%)$ & $100 \%$ \\
\hline $\begin{array}{c}\text { There are specific policy provisions } \\
\text { on how to operate and maintain } \\
\text { rail infrastructure and systems }\end{array}$ & $13(18.06 \%)$ & $13(18.06 \%)$ & $(63.88 \%$ & $\bar{z}$ & $100 \%$ \\
\hline $\begin{array}{l}\text { The railway Act or any other } \\
\text { regulatory policy provision } \\
\text { compels the continuation of } \\
\text { uncompleted projects initiated by } \\
\text { former governments }\end{array}$ & $33(45.83 \%)$ & $\bar{z}$ & $(54.17 \%)$ & $=$ & $100 \%$ \\
\hline $\begin{array}{l}\text { Rail infrastructure projects have not } \\
\text { had fair priority share among } \\
\text { other transport infrastructure } \\
\text { developments }\end{array}$ & $20(27.78 \%)$ & $=$ & (72.22\%) & $=$ & $100 \%$ \\
\hline $\begin{array}{l}\text { Partisan politics has influenced the } \\
\begin{array}{l}\text { legislative in enacting policies } \\
\text { covering sector developments }\end{array} \\
N=72\end{array}$ & $20(27.78 \%)$ & & $\begin{array}{r}33 \\
(45.83 \%) \\
\end{array}$ & $\underline{(26.39 \%)}$ & $100 \%$ \\
\hline
\end{tabular}


Table 5: Pearson's Correlations Matrix between Institutional Behavior and Rail Infrastructure

$\underline{\text { Development }}$

\begin{tabular}{|c|c|c|c|c|}
\hline \multicolumn{2}{|l|}{ Variables } & $\begin{array}{l}\frac{\text { Adequate }}{\text { monitoring, }} \\
\frac{\text { evaluation and }}{\text { discharge of }} \\
\underline{\text { duties }}\end{array}$ & $\begin{array}{l}\frac{\text { Personnel charged with }}{\text { the maintenance of rail }} \\
\frac{\text { infrastructure are }}{\text { adequately equipped to }} \\
\underline{\text { do their work }}\end{array}$ & $\begin{array}{l}\frac{\text { Partisan politics }}{\text { influence the }} \\
\frac{\text { legislative in }}{\text { enacting rail }} \\
\text { policies for } \\
\text { development. }\end{array}$ \\
\hline \multirow{3}{*}{$\begin{array}{c}\text { Adequate monitoring, } \\
\frac{\text { evaluation and }}{\text { discharge of duties }}\end{array}$} & $\underline{\text { Pearson Correlation }}$ & $\underline{1}$ & .418 & -.063 \\
\hline & $\underline{\text { Sig. (2-tailed) }}$ & & .200 & .853 \\
\hline & & $\underline{72}$ & $\underline{72}$ & $\underline{72}$ \\
\hline \multirow{3}{*}{$\begin{array}{l}\text { Personnel charged with the } \\
\text { maintenance of rail } \\
\text { infrastructure are } \\
\text { adequately equipped to } \\
\text { do their work }\end{array}$} & $\underline{\text { Pearson Correlation }}$ & .418 & $\underline{1}$ & .015 \\
\hline & $\underline{\text { Sig. (2-tailed) }}$ & .200 & & .965 \\
\hline & $\underline{\mathrm{N}}$ & $\underline{72}$ & $\underline{72}$ & $\underline{72}$ \\
\hline \multirow{3}{*}{$\begin{array}{l}\frac{\text { Partisan politics influence }}{\text { the legislative in }} \\
\text { enacting rail policies for } \\
\text { development. }\end{array}$} & $\underline{\text { Pearson Correlation }}$ & $\underline{-.063}$ & .015 & $\underline{1}$ \\
\hline & $\underline{\text { Sig. (2-tailed) }}$ & .853 & .965 & \\
\hline & $\underline{\mathrm{N}}$ & $\underline{72}$ & 72 & $\underline{72}$ \\
\hline
\end{tabular}


Table 6 - Other Negative Behavioral Impact of Rail Infrastructure Development

\begin{tabular}{|c|c|c|}
\hline Variables & Frequency & Percentage \\
\hline \multicolumn{3}{|l|}{$\begin{array}{l}\text { Railway infrastructure projects have not had fair priority share among } \\
\text { other transport infrastructure developments: }\end{array}$} \\
\hline Agree & 20 & 27.78 \\
\hline Strongly Agree & $\overline{52}$ & $\overline{72.22}$ \\
\hline \multicolumn{3}{|l|}{ The Ghanaian economy is underinvested in rail infrastructure } \\
\hline Agree & 7 & 9.72 \\
\hline Partially Agree & $\underline{20}$ & $\underline{27.78}$ \\
\hline Strongly Agree & $\underline{45}$ & $\underline{62.50}$ \\
\hline Disagree & $=$ & $\underline{0}$ \\
\hline \multicolumn{3}{|l|}{ Description of the current status of the Ghana railway sector: } \\
\hline Adequate & $\underline{7}$ & 9.72 \\
\hline$\overline{\text { Collapsing }}$ & $\underline{2 \overline{7}}$ & $\overline{37.5}$ \\
\hline Collapsed & $\underline{33}$ & 45.83 \\
\hline Virtually Collapsed & $\underline{5}$ & 6.95 \\
\hline \multicolumn{3}{|l|}{ Challenges relating to poor maintenance of rail infrastructure: } \\
\hline Lack of funds, regulation and monitoring & 13 & 18.06 \\
\hline Lack of funds and technical know-how & 13 & 18.06 \\
\hline Lack of regulation, monitoring and technical know-how & 7 & 9.72 \\
\hline Lack of funds, regulation, monitoring as well as technical know-how & $\underline{39}$ & $\underline{54.16}$ \\
\hline & & \\
\hline
\end{tabular}


Table 7A: Relationship Tests using Regression Analysis

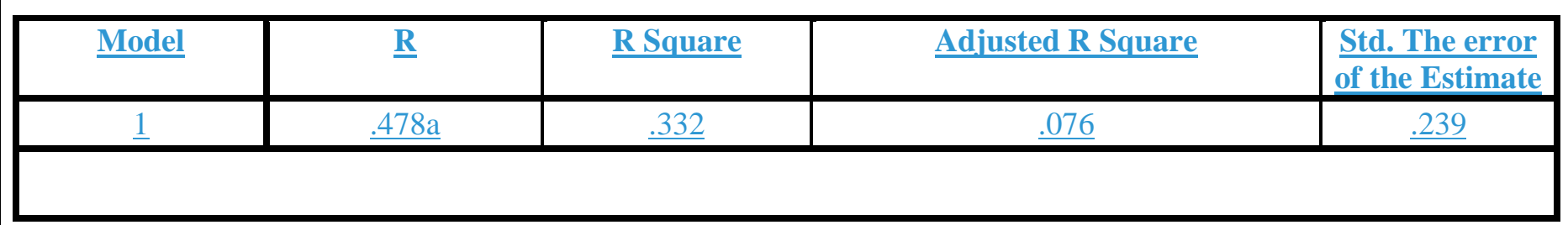

a. Predictors: (Constant), Sufficient Budget Allocation 
Table 7B: Relationship Tests using Analysis of Variance

\begin{tabular}{|c|c|c|c|c|c|}
\hline Model & $\frac{\text { Sum of }}{\text { Squares }}$ & $\underline{\text { dff }}$ & Mean Square & $\underline{F}$ & Sig. \\
\hline$\frac{1 \quad \text { Regression }}{\frac{\text { Residual }}{\text { Total }}}$ & $\frac{.207}{6.338}$ & $\begin{array}{l}\frac{1}{9} \\
\frac{1}{10} \\
\end{array}$ & $\frac{.207}{.704}$ & .295 & $.003^{b}$ \\
\hline
\end{tabular}

a. Dependent Variable: Rail infrastructure Development

b. Predictors: (Constant), Sufficient Budget Allocation 
Table 7C: Relationship Tests using Coefficient

\begin{tabular}{|c|c|c|c|c|c|}
\hline \multirow[t]{2}{*}{ Model } & \multicolumn{2}{|c|}{ Unstandardized Coefficients } & Standardized & \multirow[t]{2}{*}{$\underline{\mathrm{t}}$} & \multirow[t]{2}{*}{ Sig. } \\
\hline & $\underline{\mathrm{B}}$ & Std. Error & Beta & & \\
\hline$\frac{1 \quad \text { (Constant) }}{\text { Sufficient Budget Allocation }}$ & $\frac{2.394}{.327}$ & .513 & .178 & $\frac{4.670}{.543}$ & .001 \\
\hline
\end{tabular}

a. Dependent Variable: Rail infrastructure Development 
Table 8 - Need for Financing Reforms for Rail Infrastructure Development

\begin{tabular}{|c|c|c|c|c|c|}
\hline Variables & Agree & $\begin{array}{l}\text { Partially } \\
\text { Agree }\end{array}$ & $\begin{array}{l}\text { Strongly } \\
\text { Agree }\end{array}$ & Disagree & $\frac{\text { Per }}{\text { cent }}$ \\
\hline $\begin{array}{l}\text { The type of financing option } \\
\text { deployed for rail infrastructure } \\
\text { development influences the level } \\
\text { of investment in the sector }\end{array}$ & $\begin{array}{l}\frac{20}{(27.78 \%)} \\
\underline{\underline{y}}\end{array}$ & $\frac{13}{(18.06 \%)}$ & $39(54.16 \%)$ & $=$ & $\underline{100 \%}$ \\
\hline $\begin{array}{l}\text { There is a specifically earmarked } \\
\text { government revenue stream for } \\
\text { financing railway infrastructure } \\
\text { development }\end{array}$ & $\bar{z}$ & $\begin{array}{l}\frac{20}{(27.78 \%)} \\
\underline{y}\end{array}$ & $\bar{z}$ & $\begin{array}{l}\frac{52}{(72.22 \%)} \\
\end{array}$ & $100 \%$ \\
\hline $\begin{array}{l}\text { Ghana requires financing reforms } \\
\text { to fund rail infrastructure projects }\end{array}$ & $\frac{13}{(18.06 \%)}$ & $=$ & $\underline{59(81.94 \%)}$ & $=$ & $100 \%$ \\
\hline $\begin{array}{l}\text { The type of financing option } \\
\text { deployed for rail infrastructure } \\
\text { development influences the level } \\
\text { of investment in the sector }\end{array}$ & $\frac{20}{(27.78 \%)}$ & $\frac{13}{(18.06 \%)}$ & $39(54.16 \%)$ & $=$ & $100 \%$ \\
\hline
\end{tabular}

